Abstract 62 Table 1 Comparing patient characteristics between Caucasians and non-Caucasians

\begin{tabular}{|c|c|c|c|}
\hline & $\begin{array}{l}\text { Caucasian } \\
(\mathrm{n}=30)\end{array}$ & $\begin{array}{l}\text { Non-Caucasians } \\
(n=53)\end{array}$ & $\mathrm{p}$-value \\
\hline \multicolumn{4}{|l|}{ Socio-demographics } \\
\hline Age, years, median [IQR] & $48[41-62]$ & 39 [31-49] & 0.002 \\
\hline$\geq$ College education, $\%$ & 68 & 38 & 0.008 \\
\hline Disability, \% & 23 & 50 & 0.02 \\
\hline \multicolumn{4}{|l|}{ Marital status, $\%$} \\
\hline Single & 10 & 42 & 0.002 \\
\hline Married & 63 & 39 & \\
\hline Divorced & 17 & 19 & \\
\hline Widowed & 10 & 0 & \\
\hline Live with partner/spouse & 70 & 48 & 0.05 \\
\hline Medicaid,\% & 10 & 25 & 0.09 \\
\hline \multicolumn{4}{|l|}{ Interpersonal Process of Care } \\
\hline $\begin{array}{l}\text { Hurried communication*, } \\
\text { median [IQR] }\end{array}$ & $1[1-1.3]$ & $1.3[1-1.8]$ & 0.001 \\
\hline Elicit concerns $\dagger$, median [IQR] & $5[4.7-5]$ & $5[4.7-5]$ & 0.6 \\
\hline $\begin{array}{l}\text { Explained results } \% \text {, median } \\
{[\text { IQR] }}\end{array}$ & $4.6[3.6-5]$ & $4.8[4-5]$ & 1 \\
\hline $\begin{array}{l}\text { Patient-centered decision } \\
\text { making†, median [IQR] }\end{array}$ & $4.8[3.8-5]$ & $4.5[3.8-5]$ & 0.5 \\
\hline $\begin{array}{l}\text { Compassionate respectful }{ }^{\prime} \text {, } \\
\text { median [IQR] }\end{array}$ & $5[4.4-5]$ & $5[4.4-5]$ & 0.7 \\
\hline Discrimination*, median [IQR] & $1[1-1]$ & $1[1-1]$ & 0.2 \\
\hline $\begin{array}{l}\text { Disrespectful office staff*, } \\
\text { median [IQR] }\end{array}$ & $1[1-1]$ & $1[1-1]$ & 0.8 \\
\hline Patient-reported Outcomes & & & \\
\hline $\begin{array}{l}\text { General Self-efficacy }{ }^{\S} \text {, median } \\
\text { [IQR] }\end{array}$ & $60[49-65]$ & $51[42-62]$ & 0.06 \\
\hline $\begin{array}{l}\text { Self-efficacy in taking } \\
\text { medications }^{\S} \text {, median [IQR] }\end{array}$ & $52[43-61]$ & $50[42-54]$ & 0.3 \\
\hline Fatigue $^{\S}$, mean (SD) & $58(10)$ & $54(11)$ & 0.06 \\
\hline $\begin{array}{l}\text { Social health }{ }^{\S} \text {, mean (SD) } \\
\text { Clinical factors }\end{array}$ & $48(10)$ & $52(10)$ & 0.06 \\
\hline $\begin{array}{l}\text { Years of diagnosis, median } \\
\text { [IQR] }\end{array}$ & $20[7-26]$ & $14[8-17]$ & 0.08 \\
\hline $\begin{array}{l}\text { Rheumatic medication } \\
\text { regimen complexity score, } \\
\text { median [IQR] }\end{array}$ & $5[3-8]$ & $8[5-11]$ & 0.004 \\
\hline $\begin{array}{l}\text { SLICC damage score, median } \\
\text { [IQR] }\end{array}$ & $1[0-2]$ & $2[1-3]$ & 0.06 \\
\hline SLEDAI, median [IQR] & $1[0-4]$ & $4[1-8]$ & 0.03 \\
\hline SLAQ, median [IQR] & $11[6-14]$ & $9[6-13]$ & 0.7 \\
\hline $\begin{array}{l}\text { Fibromyalgia symptom } \\
\text { severity score, median [IQR] }\end{array}$ & $4(2)$ & $3(2)$ & 0.04 \\
\hline
\end{tabular}

$\mathrm{IQR}=$ interquartile range; $\mathrm{SD}=$ standard deviation; $\mathrm{SLAQ=systemic}$ lupus activity question naire; SLEDAl=systemic lupus erythematosus disease activity index; SLICC=systemic lupus international collaborating clinics

* Scores range from 1-5, with lower being better

†Scores range from 1-5, with higher being better

${ }^{5} \mathrm{~A}$ score of 50 represents the US population mean, a difference in 5 is clinically significant. Higher scores are better for self-efficacy and social health, but lower scores are better for fatigue.

Funding Source(s): 5U54MD012530-02

\section{METABOLIC SYNDROME IN LUPUS AND RELATIONSHIP WITH THE NEUTROPHIL TO LYMPHOCYTE RATIO}

Vanessa Castro*, Demelza D Yucra, Gabriela Garate, Hamaui Adriana, Diana Dubinsky. Sanatorio Guemes

\subsection{6/lupus-2019-Ism.63}

Background In SLE there is five times more risk of cardiovascular events (CV) compared to the general population. In Argentina, a prevalence of metabolic syndrome (MetS) was reported in 28\%. The SLICC cohort found 36.5\% of MS in the first 2 years of diagnosis.

The neutrophil to lymphocyte ratio (NLR) is a marker of inflammation that relates the absolute count of neutrophils and lymphocytes, is a tool in the assessment of CV risk and systemic endothelial dysfunction. The NLR values reported in healthy is $1.65( \pm 1.47)$. Studies in SLE show that NLR is a marker of activity and nephritis.

We aimed to determine the association of MetS with and without renal involvement, the relationship between NLR and MetS and relationship between NLR and disease activity.

Methods Descriptive, cross-sectional study.

Patients with SLE (SLICC 2012) of $<5$ years of evolution and $>18$ years followed at the Güemes Hospital were included, between $06 / 2013$ to $07 / 2018$.

Acute CV events, infections, pregnancy, diabetes and chronic kidney disease were excluded.

Risk factors nontraditional were determined: antiphospholipid (aPL), GC, SLEDAI.

MetS (NCEP ATP III criteria): Weight, height, abdominal perimeter (AP) and blood pressure.

PCR, neutrophil and lymphocyte count, glucose, CT, TG, LDL, urea, creatinine, proteinuria/24hs, Anti DNA, C3, C4, aPL: LA, Anti B2GP and Anti aCL antibody.

Statistical Analysis: Epi Info 7.2.0.

Results A total of 42 patients were reviewed, 12 were excluded (incomplete data).

Of 30 patients: 23 women (77\%), mean age 39.3 ( \pm SD 14.3), evolution of disease: 35 months ( \pm SD 18.9), tobacco exposure: 11 (37\%). Nephritis in 17 patients (51\%).

MetS: 13 (43.3\%), components: AP increased 15 (50\%), HDL low 11 (37\%), hypertension 11 (37\%), high TG 8 (27\%), hyperglycemia 3 (10\%). Overweight: 17 (57\%).

Mean BMI 27.4 ( \pm DS 6.2).

Characteristics of patients with and without MetS and relationship MetS and SLE with NLR. (Table).

Conclusions In our series, a greater frequency of MetS was found than literature. No relationship was found between MetS with renal involvement; however patients with MetS had higher proteinuria and elevated CRP.

No relationship was found between the NLR with MetS and nephritis. The NLR was higher in patients with SLEDAI 4.

The high prevalence of MetS, proteinuria, elevated CRP and NLR in our population suggest persistent inflammatory activity and probable CV morbidity, so it is important to detect it from the onset of the disease.

Funding Source(s): None 
Abstract 63 Table 1 Characteristics of patients with and without MetS and relationship MetS and SLE with NLR

\begin{tabular}{|c|c|c|c|}
\hline & MetS $n=13$ & Non MetS $n=17$ & \\
\hline $\begin{array}{l}\text { Female }(\%) \\
\text { Age years }( \pm \text { SD) } \\
\text { Smoking exposure (\%) } \\
\text { NLR (IQR) } \\
\text { BMI ( } \pm \text { SD) } \\
\text { Nephritis }(\%) \\
\text { Proteinuria gr/24 hrs }( \pm \text { SD) } \\
\text { Class III / IV } \\
\text { CRP mg/dl ( } \pm \text { SD) } \\
\text { aPL + }(\%) \\
\text { SLEDAl }( \pm \text { SD) } \\
\text { SLICC }( \pm \text { SD) } \\
\text { Accumulated corticoid gr }( \pm \text { SD) } \\
\text { HCQ (\%) } \\
\text { ASA (\%) }\end{array}$ & $\begin{array}{l}10(77) \\
38.6(12.7) \\
5(38) \\
3.42(1.28-5.67) \\
31(7.2) \\
7(54) \\
1.5(3.19) \\
4 / 7(57) \\
8.7(10) \\
6(46) \\
2.8(3.5) \\
0.23(0.43) \\
6.74(4.6) \\
12(92) \\
3(23)\end{array}$ & $\begin{array}{l}13(76) \\
40(15.7) \\
6(35) \\
3.05(1-6) \\
25(4) \\
10(58) \\
0.35(0.54) \\
6 / 10(60) \\
7.61(22) \\
4(23) \\
2.4(2.52) \\
0.23(0.43) \\
9.43(5.9) \\
17(100) \\
4(24)\end{array}$ & $\begin{array}{l}0.49 \\
0.62 \\
0.43 \\
0.52 \\
0.02 \\
0.39 \\
0.03 \\
0.45 \\
0.02 \\
0.11 \\
0.74 \\
0.97 \\
0.25 \\
0.21 \\
0.49\end{array}$ \\
\hline & NLR ( $\pm \mathrm{DS})$ & $p$ & \\
\hline $\begin{array}{l}\text { MetS } \\
\text { MetS } \geq 4 \text { criteria } \\
\text { Nephritis } \\
\text { SLEDAI } \geq 4 \\
\text { CRP }>5\end{array}$ & $\begin{array}{l}3.42(1.32) \\
3.77(3.77) \\
3.35(1.62) \\
4.43(1.42) \\
3.87(1.50)\end{array}$ & $\begin{array}{l}0.52 \\
0.61 \\
0.67 \\
0.027 \\
0.11\end{array}$ & \\
\hline
\end{tabular}

\section{ANA BY INDIRECT IMMUNOFLUORESCENCE ALONE RARE IN SLE AND CLINICAL PHENOTYPE OF PATIENTS WITH ANA PLUS LUPUS ASSOCIATED ANTIBODIES IS DIFFERENT THAN ANA ALONE}

H Michael Belmont*, Peter Izmirly, Jill Buyonm. NYU School of Medicine

\subsection{6/lupus-2019-Ism.64}

Background Autoantibody and laboratory testing is essential for SLE diagnosis. ANA by indirect immunofluorescence (ANA IIF) remains the gold standard to screen for lupus and studies demonstrate preclinical phase during which autoantibodies accumulate. Prevalence of ANA IIF alone without more specific autoantibodies and the accompanying clinical phenotype of these patients uncertain.

Methods Queried 602 patients in the NYU Lupus Registry with 4 or more ACR or SLICC criteria as adjudicated by the authors for prevalence of ANA IIF, dsDNA, Sm, Ro, La, RNP, aPL, C3, C4. Compared clinical features of isolated ANA (ANA IIF alone) with the ANA IIF plus one or more lupus associated abnormalities (ANA IIF +).

Results 590/602 (98\%) ANA IIF positive. 548/590 (93\%) patients at least one of associated tests compared to only 42/ 590 (7\%) ANA IIF alone. SLE nephritis significantly more prevalent in ANA IIF+254/548 (46\%), compared to $13 / 42$ (31\%) recorded with renal criteria ANA IIF alone. ANA IIF +, 158/254 (62\%) biopsy proven nephritis (LN), rather than relying on proteinuria for diagnosis, compared to $5 / 13(38 \%)$ of ANA IIF alone biopsy proven LN. Remaining 8 ANA IIF alone, uPCR exceeded $0.5 \mathrm{~g}$ in 1 of $44(2 \%)$ encounters. Low incidence of proteinuria explained by complete renal response or prior proteinuria misconstrued as evidence of LN. In comparison, uPCR $>0.5 \mathrm{~g}$ was present in 694 of 1157 (60\%) encounters in ANA IIF +, casting doubt on validity of LN diagnosis in 8 ANA IIF alone without biopsy.
Leucopenia, lymphocytopenia, AITP, AIHA statistically less ANA IIF alone compared to ANA IIF + ; $24 \%$ vs $36 \%$, $29 \%$ vs $40 \%, 7 \%$ vs $15 \%$ and $0 \%$ vs $7 \%$, respectively. 42 patients with ANA IIF alone prevalence of potentially misattributed (e.g. not result of IMID) clinical criteria such as photosensitivity (64\%) and malar rash (60\%) greater compared to ANA IIF +, 38\% and 44\%, respectively. Prevalence oral ulcers, DLE, arthritis, serositis, seizures and psychosis equivalent in both.

\begin{tabular}{|c|c|c|c|}
\hline & ANA IIF + & $\begin{array}{l}\text { ANA IIF } \\
\text { alone }\end{array}$ & P Value \\
\hline $\mathrm{n}$ & $548 / 590(93 \%)$ & $42 / 590(7 \%)$ & $<0.001$ \\
\hline Nephritis & $254 / 548(46 \%)$ & $13 / 42(31 \%)$ & $=0.0442$ \\
\hline GN by biopsy & 158/254 (62\%) & $5 / 13(38 \%)$ & $=0.1222$ \\
\hline GN by proteinuria & 96/254 (38\%) & $8 / 13(62 \%)$ & $=0.1222$ \\
\hline Visits with & $694 / 1157$ & $1 / 44(2 \%)$ & $<0.0001$ \\
\hline $\mathrm{uPCR}>0.5$ & $(60 \%)$ & & \\
\hline Malar rash & $44 \%$ & $60 \%$ & $=0.1163$ \\
\hline Photosensitivity & $38 \%$ & $64 \%$ & $=0.0018$ \\
\hline AITP & $15 \%$ & $7 \%$ & $=0.0544$ \\
\hline AlHA & $7 \%$ & $0 \%$ & $<0.0001$ \\
\hline Leucopenia & $36 \%$ & $24 \%$ & $=0.0254$ \\
\hline Lymphocytopenia & $40 \%$ & $29 \%$ & $=0.0888$ \\
\hline Oral ulcers & $24 \%$ & $26 \%$ & NS \\
\hline DLE & $22 \%$ & $33 \%$ & NS \\
\hline Arthritis & $70 \%$ & $69 \%$ & NS \\
\hline Serositis & $27 \%$ & $31 \%$ & NS \\
\hline Seizures & $4 \%$ & $2 \%$ & NS \\
\hline Psychosis & $2 \%$ & $5 \%$ & NS \\
\hline
\end{tabular}

ACR Clinical Criteria ANA IIF alone vs ANA IIF + 